\title{
THE INFLUENCE OF INTEREST RATE, MONEY CIRCULATION, INFLATION, AND CPI AGAINST EXPORT AND IMPORT IN INDONESIA 2012-2018
}

\section{Fazhar Sumantria, Umi Latifah}

Sistem Informasi Akuntansi, Teknologi Informasi, Universitas Bina Sarana Informatika Jakarta fazhar.fzs@bsi.ac.id

\begin{tabular}{|c|c|}
\hline Info article & Abstract \\
\hline $\begin{array}{l}\text { Article history: } \\
\text { Received November } 11,2019 \\
\text { Revised November } 30,2019 \\
\text { Accepted December 20, } 2019 \\
\text { Available online December } \\
31,2019\end{array}$ & $\begin{array}{l}\text { Indonesia's economic growth can no longer depends on } \\
\text { internal trade only but needs to depend on the export and } \\
\text { import with the global market, thus macroeconomic } \\
\text { influence towards export and import needs further research. } \\
\text { Thus, this research focuses on the effect of multiple } \\
\text { macroeconomic variables which are the rate of loans, } \\
\text { money supply, inflation and consumer price index towards }\end{array}$ \\
\hline $\begin{array}{l}\text { Keyword: } \\
\text { Consumer Price Index; Export; } \\
\text { Import; Inflation; Money } \\
\text { Supply } \\
\text { JEL Classification : E31; } \\
\text { F10; E51 }\end{array}$ & $\begin{array}{l}\text { export and import in Indonesia. The data used in this } \\
\text { research are secondary data acquired from BPS, BI and the } \\
\text { Ministry of Trade during the periode of 2012-2018, which } \\
\text { are analyzed using the classic assumption tests (normality } \\
\text { test, autocorrelation test, heteroscedasticity test, and } \\
\text { multicollinearity test) followed by the multiple regression } \\
\text { analysis. Based on the F test we concluded that all the } \\
\text { dependent variables are simultaneously effecting both } \\
\text { import and export, while the T test shows that only the } \\
\text { Consumer Price Index does not have any effect towards } \\
\text { both import and export while the other variables effect both } \\
\text { import and export, this signifies that Consumer Price Index } \\
\text { does not need to be considered in analyzing and forecasting } \\
\text { of both import and export. }\end{array}$ \\
\hline
\end{tabular}

\section{INTRODUCTION}

Macroeconomic variables as indicators that influence economic trade cannot be separated from daily economic activities, especially in conditions where Indonesia cannot be separated from international trade activities so that export and import transactions need special attention and in-depth research, this can be seen from various studies that have been done by previous researchers.

The several indicators of economic growth referred to based on previous researchers can be described as follows; The first indicator is the Credit Interest Rate which is the percentage value of the interest rate or the value of the money borrowed that is used to buy necessities (Putra, 2018). Accompanied by the variable Amount of Money Supply is the amount of money circulating in the community and money in deposits and foreign exchange accounts (Langi, Maisnambow, \& Siwu, 2014). Then, inflation is calculated based on the percentage of the condition of the price of goods that increase and the decline in the value of a country's currency (Aldina, Susyanti, \& Salim, 2019). The last indicator in this study is the Consumer Price Index (CPI) which is an index to calculate the increase and decrease in the price of goods or services purchased 
by the public (Wardani, 2019). These indicators can affect export and import trade in a country, while what is meant by exports and imports are as follows; Export is an activity of selling goods or services of a country to be sold to other countries (Suhendro \& Siregar, 2019). Meanwhile, import is an activity of purchasing goods or services from other countries into the country (Yudhanto, Arifin, \& Yulianto, 2019).

One of the drivers of economic growth is exports and imports. Exports in economic growth aim to meet the needs of foreign markets and increase consumption of a country so as to increase foreign exchange and income per capita (Suhendro \& Siregar, 2019). In contrast to import activities, imports in economic growth aim to meet the needs of the community and can increase foreign exchange reserves. However, high import activities can cause a decrease in domestic production so that the purchase price of an item or service will also decline (Ismanto, Rina, \& Kristini, 2019).

(Mahendra \& Kesumajaya, 2015) conducted a study entitled "Analysis of the Effects of Investment, Inflation, US Dollar Exchange Rates and Credit Interest Rates on Indonesian Exports in 1992-2012" in his research found that Credit Interest Rates and Inflation had a significant effect on exports. (Suryono, 2019) conducted a study on "The Effect of Exchange Rates and Money Supply on Indonesian Exports in 2009-2018" from his research found that the money supply has a significant effect on exports and has a positive relationship between the money supply and exports which means each an increase in the money supply can increase exports.

(Anshari, Khilla, \& Permata, 2017) conducted research on "Analysis of the Influence of Inflation and Exchange Rates on Exports in ASEAN 5 Periods 2012-2018" in his research stated that Inflation has a significant effect on exports in ASEAN countries and Inflation has a positive relationship with Exports where each increase in the value of inflation will increase the value of exports. (Kurniasari \& Monica, 2019) researching on "The Effect of Exchange Rates, Indonesian Interest Rates and Gross Domestic Products on the Import and Export Volume in Indonesia" in his research it was concluded that Interest Rates had a simultaneous effect. However, interest rates have no significant partial effect.

(Junaidi, Sulasmiyati, \& Nurlaily, 2018) examined the "Effect of National Income, Inflation and Yuan Exchange Rates on Indonesian Imports from China for the 2010-2017 Period" from his research it can be concluded that Inflation has a simultaneous effect on Imports. However, partial inflation did not have a significant effect on imports. (Sonia \& Setiawina, 2016) conducted research on "Effects of Exchange Rate, the amount of money in circulation and Inflation Rate on Indonesian Exports, Imports and Foreign Reserves" based on his research found that the Amount of Money Supply has a positive effect on Imports.

The purpose of this study is to determine the effect of economic growth indicators on exports and imports as an analysis of economic growth in 
Indonesia, while previous research focuses much on exports and imports as independent variables while in this study both of these variables will be dependent variables while the independent variables in this study are Tribes Credit Interest, Money Supply, Inflation and the Consumer Price Index because these variables can affect exports and imports, but need further verification through this research.

\section{RESEARCH METHODS}

The data source used in this study is secondary data. Secondary data is data that is not obtained from the source directly, but is obtained from other sources both through individuals and documents (Maharani, Setiawina, \& Purbadharmaja, 2017). Data in this study were obtained from the Central Statistics Agency (BPS), Bank Indonesia (BI), and the Ministry of Trade (Ministry of Trade) in the period 2012-2018.

The analytical method used in this study uses multiple linear regression analysis models (multiple regression analysis model) using SPSS version 17, testing is carried out using the normality test, autocorrelation test, heteroscedasticity test, simultaneous $\mathrm{F}$ test, partial $\mathrm{t}$ test, and coefficient of determination.

\section{RESULT AND DISCUS}

The regression equation model for exports is as follows:

$$
\mathrm{Y}_{1}=53505.532-537.137 \mathrm{X}_{1}-0.001 \mathrm{X}_{2}+270.606 \mathrm{X}_{3}-42.520 \mathrm{X}_{4}
$$

Table 1. Analysis of Multiple Linear Regression Against Exports

\begin{tabular}{lccc}
\hline & \multicolumn{2}{c}{ Unstandardized } & Standardized \\
& \multicolumn{2}{c}{ Coefficients } & Coefficients \\
& $\mathrm{B}$ & Std. Error & Beta \\
\hline (Constant) & 53505.532 & 7966.291 & \\
Loan Interest Rates & -537.137 & 93.021 & -.974 \\
Total Money Supply & -.001 & .000 & -.625 \\
Inflation & 270.606 & 106.349 & .299 \\
CPI & -42.520 & 23.308 & -.243 \\
\hline
\end{tabular}

source: processed data follows:

Based on the above calculation, the results of the equation can be concluded as

a. The constant ( $\alpha$ ) of 53505,532 shows the constant of (Y1), assuming the value of each independent variable (X1, X2, X3, X4) is constant.

b. The Credit Interest Regression Coefficient (X1) of -537,137 states that there is a negative relationship, which means that the Credit Interest Rates with Exports show the opposite direction, meaning that any increase in the value of the Credit Interest Rates will result in a decrease in the value of Exports and any reduction in the Credit Interest Rates will result increase in export value.

c. The Coefficient of the Money Supply (X2) of -0.001 states that there is a negative relationship, which means that the Amount of Money Supply and Exports shows the opposite direction, meaning that any increase in the value 
of the Money Supply will cause a decrease in the value of Exports and any decrease in the Amount of Money Supply will result in an increase Value of Export.

d. The inflation coefficient (X3) of 270,606 states that there is a positive relationship, which means that inflation and exports show a direct relationship, meaning that any increase in inflation will cause an increase in the value of exports and any decrease in inflation will result in a decrease in the value of exports.

e. The CPI coefficient (X4) of $-42,520$ indicates a negative relationship, which means that the CPI and exports show the opposite direction, meaning that any increase in CPI will result in a decrease in the value of exports and any decline in CPI will result in an increase in the value of exports.

Table 2. Analysis of Multiple Linear Regression Against Imports

\begin{tabular}{lccc}
\hline \multirow{1}{c}{ Model } & \multicolumn{2}{c}{ Unstandardized } & Standardized \\
& Coefficients & Coefficients \\
& B & Std. Error & Beta \\
\hline (Constant) & 68080.390 & 11004.555 & \\
Loan Interest Rates & -743.869 & 128.498 & -.991 \\
Total Money Supply & -.002 & .000 & -.591 \\
Inflation & 408.540 & 146.910 & .331 \\
CPI & -60.832 & 32.198 & -.255 \\
\hline
\end{tabular}

source: processed data

The regression equation model for imports as follows:

$\mathrm{Y} 2=68080,390-743,869 \mathrm{X} 1-0.002 \mathrm{X} 2+408,540 \mathrm{X} 3-60,832 \mathrm{X} 4$

Based on the above calculation, the following can be obtained:

a. The constant ( $\alpha$ ) of 68080,390 shows the constant of (Y1), assuming the value of each independent variable (X1, X2, X3, X4) is constant.

b. Credit Interest Regression Coefficient (X1) of $-743,869$ stated that there was a negative relationship, which means that the Credit Interest Rates with Imports showed the opposite direction, meaning that any increase in the value of the Credit Interest Rates would result in a decrease in the value of Imports and any decrease in the Credit Interest Rates would result Increase in Import value.

c. The Coefficient of the Money Supply (X2) of -0.002 states that there is a negative relationship, which means that the Amount of Money Supply and Imports shows the opposite relationship, meaning that any increase in the value of the Money Supply will cause a decrease in the value of Imports and any decrease in the Amount of Money Supply will result in an increase Import value.

d. The Inflation Coefficient (X3) of 408,540 states that there is a positive relationship, which means that Inflation with Imports shows a unidirectional relationship, meaning that any increase in the value of Inflation will cause an increase in the value of Imports and any decrease in Inflation will result in a decrease in the value of Imports. 
e. The CPI coefficient (X4) of $-60,832$ states that there is a negative relationship, which means that the CPI and Imports show an opposite direction, meaning that any increase in CPI will result in a decrease in the value of Imports and any decrease in CPI will result in an increase in Import value.

\section{Normality test}

This test is conducted to determine whether the regression model in this study has a normal data distribution or close to normal data or not. The display results of the graphs in the X1, X2, X3, X4 studies of Y1 and Y2 show that the points spread around the diagonal line and follow the direction of the diagonal line, then this regression model meets the normality assumption which means the data has normal distribution.

\section{Autocorrelation Test}

According to (Andari, Arifati, \& Andini, 2016) this test can be used to detect autocorrelation problems by using the DurbinWatson (DW) test, namely:

a. DW number below -2 means there is a positive autocorrelation.

b. DW numbers between -2 to 2 , means there is no autocorrelation.

c. DW numbers above 2 mean there is a negative autocorrelation.

Table 3. Durbin Watson Against Exports

\begin{tabular}{crrrrr}
\hline Model & R & R Square & $\begin{array}{c}\text { Adjusted R } \\
\text { Square }\end{array}$ & $\begin{array}{l}\text { Std. Error of } \\
\text { the Estimate }\end{array}$ & $\begin{array}{l}\text { Durbin- } \\
\text { Watson }\end{array}$ \\
\hline 1 & $.686^{\mathrm{a}}$ & .470 & .444 & 1190.67394 & 1.401
\end{tabular}

a. Predictors: (Constant), CPI, Amount of Money Supply, Inflation, Credit Interest Rates

b. Dependent Variable: Export

Table 4. Durbin Watson Against Imports

\begin{tabular}{crrrrr}
\hline Model & R & R Square & $\begin{array}{c}\text { Adjusted R } \\
\text { Square }\end{array}$ & $\begin{array}{l}\text { Std. Error of } \\
\text { the Estimate }\end{array}$ & $\begin{array}{c}\text { Durbin- } \\
\text { Watson }\end{array}$ \\
\hline 1 & $.675 \mathrm{a}$ & .455 & .427 & 1644.78521 & 1.365
\end{tabular}

a. Predictors: (Constant), CPI, Amount of Money Supply, Inflation, Credit Interest Rates

b. Dependent Variable: Import

Based on the results of the analysis using SPSS in tables 3 and 4 above obtained DW values above 1 , which means that the regression model of the influence of Credit Interest Rates, Money Supply, Inflation, and CPI on Exports and Imports does not contain autocorrelation.

\section{Heteroscedasticity Test}

This test is carried out to detect the presence or absence of heteroscedasticity by looking at the pattern of points on scatterplots regression. The results of the graphs in studies $\mathrm{X} 1, \mathrm{X} 2, \mathrm{X} 3, \mathrm{X} 4$ against $\mathrm{Y} 1$ and $\mathrm{Y} 2$ show that the pattern of points does not form a specific pattern and spreads above and below the numbers 0 on the $X$ and $Y$ axes, it can be concluded that there is no heteroscedasticity in the model this regression. 


\section{Multicollinearity Test}

Symptoms of multicollinearity are detected if the VIF (variance inflation factor) value $>10$. If the $\mathrm{VIF}$ value $<10$ then the multiple linear regression model is not found correlation between the independent variables (Appa, 2014).

Table 5. Multicollinearity Test Against Exports

\begin{tabular}{lcc}
\hline \multicolumn{1}{c}{ Model } & \multicolumn{2}{c}{ Collinearity Statistics } \\
& Tolerance & VIF \\
\hline (Constant) & & \\
Loan Interest Rates & .236 & 4.244 \\
Total Money Supply & .592 & 1.690 \\
Inflation & .486 & 2.058 \\
CPI & .379 & 2.637 \\
\hline
\end{tabular}

a. Dependent Variable: Eksport

source: processed data

Table 6. Multicollinearity Tests on Imports

\begin{tabular}{lcc}
\hline \multirow{2}{*}{ Model } & \multicolumn{2}{c}{ Collinearity Statistics } \\
& Tolerance & VIF \\
\hline (Constant) & & \\
Loan Interest Rates & .236 & 4.244 \\
Total Money Supply & .592 & 1.690 \\
Inflation & .486 & 2.058 \\
CPI & .379 & 2.637 \\
\hline
\end{tabular}

a. Dependent Variable: Import

source: processed data

Based on tables 5 and 6 above, it can be concluded that the variable credit interest rates, money supply, inflation and CPI to exports and imports have a VIF (Variance Inflation Factor) value $<10$ and a tolerance value $>0.1$ which means that there is no multicollinearity between independent variables Export and Import.

\section{Significant F Test (Simultaneous)}

Significant F Test (Simultaneous) is used to test the effect of all independent variables on the independent variables together (Karlina, 2017).

Table 7. Test F (Simultaneous) Against Exports

\begin{tabular}{lrrrrr}
\hline Model & $\begin{array}{c}\text { Sum of } \\
\text { Squares }\end{array}$ & Df & Mean Square & F & Sig. \\
\hline Regression & $9.947 \mathrm{E} 7$ & 4 & $2.487 \mathrm{E} 7$ & 17.540 & $.000^{\mathrm{a}}$ \\
Residual & $1.120 \mathrm{E} 8$ & 79 & 1417704.430 & & \\
Total & $2.115 \mathrm{E} 8$ & 83 & & & \\
\hline
\end{tabular}

a. Predictors: (Constant), CPI, Amount of Money Supply, Inflation, Credit Interest Rates

b. Dependent Variable: Export

source: processed data 
The Influence Of Interest Rate, Money Circulation, Inflation, Sumantria

Table 8. Test F (Simultaneous) Against Imports

\begin{tabular}{lrrrrr}
\hline Model & $\begin{array}{r}\text { Sum of } \\
\text { Squares }\end{array}$ & Df & Mean Square & F & \multicolumn{1}{l}{ Sig. } \\
\hline Regression & $1.784 \mathrm{E} 8$ & 4 & $4.460 \mathrm{E} 7$ & 16.487 & $.000^{\mathrm{a}}$ \\
Residual & $2.137 \mathrm{E} 8$ & 79 & 2705318.377 & & \\
Total & $3.921 \mathrm{E} 8$ & 83 & & & \\
\hline
\end{tabular}

a. Predictors: (Constant), CPI, Amount of Money Supply, Inflation, Credit Interest Rates

b. Dependent Variable: Import

source: processed data

Based on tables 7 and 8 above obtained a significant value of $0,000<0.05$. This shows that the independent variables (Credit Interest Rates, Money Supply, Inflation and CPI) simultaneously influence exports and imports.

\section{Significance Test t (Partial)}

The Significance Test $t$ is used to test the extent of the influence of the independent variable in explaining the dependent variable partially (Wibowo \& Syaichu, 2013).

Table 9. Test (partial) on exports

\begin{tabular}{lrr}
\hline \multicolumn{1}{c}{ Model } & \multicolumn{2}{c}{ Sig. } \\
\hline (Constant) & 6.716 & .000 \\
Loan Interest Rates & -5.774 & .000 \\
Total Money Supply & -5.870 & .000 \\
Inflation & 2.545 & .013 \\
CPI & -1.824 & .072 \\
\hline
\end{tabular}

a. Dependent Variable: Eksport

source: processed data

Table 10. T Test (partial) on Imports

\begin{tabular}{lrr}
\hline \multicolumn{1}{c}{ Model } & $\mathrm{t}$ & \multicolumn{2}{c}{ Sig. } \\
\hline (Constant) & 6.187 & .000 \\
Loan Interest Rates & -5.789 & .000 \\
Total Money Supply & -5.476 & .000 \\
Inflation & 2.781 & .007 \\
CPI & -1.889 & .063 \\
\hline
\end{tabular}

a. Dependent Variable: Import

source: processed data

Based on the significance value of the SPSS output results in tables 9 and 10 above, if the Sig. $<0.05$ then the independent variable $(X)$ has a significant effect on the related variable $(\mathrm{Y})$. However, if the value of Sig. $>0.05$ then the independent variable (X) does not significantly influence the related variable $(\mathrm{Y})$. $\mathrm{T}$ test results in tables 9 and 
10 above can be concluded that the Credit Interest Rate, the Amount of Money Supply and Inflation have a value $<0.05$ which means that the Credit Interest Rate, the Amount of Money Supply and Inflation has a significant effect on Exports and Imports. Meanwhile, the CPI has a value> 0.05 which means that the CPI does not have a significant effect on exports and imports.

\section{The Coefficient Of Determination Results}

The coefficient of determination is a tool to measure how far the percentage (\%) effect of all independent variables on the dependent variable (Wibowo \& Syaichu, 2013).

Table 11. Results of Determination Coefficients on Exports

\begin{tabular}{crrrrr}
\hline Model & R & R Square & $\begin{array}{c}\text { Adjusted R } \\
\text { Square }\end{array}$ & $\begin{array}{l}\text { Std. Error of } \\
\text { the Estimate }\end{array}$ & $\begin{array}{l}\text { Durbin- } \\
\text { Watson }\end{array}$ \\
\hline 1 & $.686^{\mathrm{a}}$ & .470 & .444 & 1190.67394 & 1.401 \\
\hline
\end{tabular}

a. Predictors: (Constant), CPI, Amount of Money Supply, Inflation, Credit Interest Rates

b. Dependent Variable: Export

source: processed data

Table 12. Results of the Determination Coefficient on Imports

\begin{tabular}{crrrrr}
\hline Model & R & R Square & $\begin{array}{c}\text { Adjusted R } \\
\text { Square }\end{array}$ & $\begin{array}{c}\text { Std. Error of } \\
\text { the Estimate }\end{array}$ & $\begin{array}{l}\text { Durbin- } \\
\text { Watson }\end{array}$ \\
\hline 1 & $.675 \mathrm{a}$ & .455 & .427 & 1644.78521 & 1.365
\end{tabular}

a. Predictors: (Constant), CPI, Amount of Money Supply, Inflation, Credit Interest Rates

b. Dependent Variable: Export

source: processed data

Based on table 11 above, the value of the coefficient of determination (Adjusted $\mathrm{R}$ Square) of 0.444. This can be explained that Exports (Y1) are influenced by $44.4 \%$ by the variable Credit Interest Rates (X1), Money Supply (X2), Inflation (X3), and CPI (X4) while the rest are explained or influenced by other variables outside the model namely for $(100 \%-44.4 \%=55.6 \%)$. Meanwhile, in table 12 above, the Determination Coefficient (Adjusted R Square) value is 0.427 . This can be explained that Import (Y2) is influenced by $42.7 \%$ by the variable Credit Interest Rate (X1), Money Supply (X2), Inflation (X3), and CPI (X4) while the rest is explained or influenced by other variables outside the model namely for $(100 \%-42.7 \%=57.3 \%)$.

\section{DISCUSSION}

Based on previous research, it was found that the variable Credit Interest Rates, the Amount of Money Supply, Inflation had a significant effect on exports, however, the variable Credit Interest Rates and the Amount of Money Supply in this study had a negative effect. Meanwhile, the variable credit interest rate, inflation in previous studies did not have a significant effect partially on imports and there was no positive effect on the variable amount of money supply to imports. However, in this study Credit Interest Rates and Inflation have a partially significant effect on imports and the amount of money in circulation has a negative effect on imports. 


\section{CONCLUSION}

Based on the results of the above research conclusions can be drawn as follows: On the results of the simultaneous test analysis (F test), it shows that $\mathrm{X} 1, \mathrm{X} 2, \mathrm{X} 3$, and $\mathrm{X} 4$ on $\mathrm{Y} 1$ and $\mathrm{Y} 2$ have a significant value $<0.05$ which means that the variable Credit Interest Rates, Money Supply, Inflation and CPI have a significant effect on exports and imports and the partial test results ( $t$ test), showed that, the Credit Interest Rate, the Amount of Money Supply and Inflation had a significant value $<0.05$ which means that the Credit Interest Rate, the Amount of Money Supply and Inflation had a significant effect on exports and imports. However, in the partial test in the CPI variable, the CPI has a significant value $>0.05$ which means that the CPI has no significant effect on exports and imports. Based on the Adjusted R Square test, the results show that interest rates, money supply, inflation, and CPI affect exports by $44.4 \%$ and affect imports by $42.7 \%$. While the remaining $55.6 \%$ and $57.3 \%$ are influenced by other factors outside the model.

\section{REFERENCES}

Aldina, S., Susyanti, J., \& Salim, M. A. (2019). Pengaruh Inflasi, Kurs, BI Rate, Obligasi dan $\mathrm{PPh}$ Badan Terhadap Indeks Harga Saham Gabungan (IHSG) (Studi Kasus Pada Perusahaan Manufaktur Sektor Property Dan Real Estate Yang Terdaftar Di BEI Tahun 2015-2017 ). Jurnal Ilmiah Riset Manajemen, 8(05). Retrieved from http://www.riset.unisma.ac.id/index.php/jrm/article/view/2240/2123

Andari, Y., Arifati, R., \& Andini, R. (2016). Pengaruh Perputaran Barang Jadi, Arus Kas, Piutang, dan Aktiva Tetap Terhadap Profitabilitas Pada Perusahaan Perdagangan Eceran Yang Terdaftar Di Bei Periode 2009 2014. Journal Of Accounting, 2(2), 1-9.

Anshari, M. F., Khilla, A. El, \& Permata, I. R. (2017). Analisis Pengaruh Inflasi dan Kurs Terhadap Ekspor di Negara ASEAN 5 Periode 20122018. INFO ARTHA, 1(2), 121-128.

Appa, Y. (2014). Pengaruh Inflasi dan Kurs Rupiah/Dolar Amerika Terhadap Indeks Harga Saham Gabungan (IHSG) di Bursa Efek Indonesia (BEI), 2(4), 498-512. Retrieved from http://ejournal.adbisnis.fisipunmul.ac.id/site/wp-content/uploads/2014/10/eJOURNAL YUNI APPA 1102095123 (10-20-14-01-49-29).pdf

Badan Pusat Statistik. (2019). Badan Pusat Statistik. Retrieved November 13, 2019, from https://www.bps.go.id/

Bank Indonesia. (2019). Bank Indonesia Official Web Site - Bank Sentral Republik Indonesia. Retrieved November 13, 2019, from https://www.bi.go.id/id/Default.aspx

Ismanto, B., Rina, L., \& Kristini, M. A. (2019). Pengaruh Kurs dan Impor Terhadap Pertumbuhan Ekonomi Indonesia Periode Tahun 2007-2017. Ecodunamika. Retrieved from www.indonesia-investments.com

Junaidi, S. K., Sulasmiyati, S., \& Nurlaily, F. (2018). Pengaruh Pendapatan Nasional, Inflasi dan Nilai Tukar Yuan Terhadap Impor Indonesia dari China Periode 2010-2017. Jurnal Administrasi Bisnis, 60(2), 111-118. 
Karlina, B. (2017). Pengaruh Tingkat Inflasi, Indeks Harga Konsumen Terhadap PDB di Indonesia Pada Tahun 2011-2015. Jurnal Ekonomika Dan Manajemen, 6(1), 2252-6226. Retrieved from http://fe.budiluhur.ac.id/wp-content/uploads/2017/08/b.-berlian.pdf

Kementerian Perdagangan Republik Indonesia. (2019). Kementerian Perdagangan Republik Indonesia | Statistik. Retrieved November 13, 2019, from https://www.kemendag.go.id/id/economic-profile

Kurniasari, F., \& Monica, L. (2019). Pengaruh Nilai Tukar, Suku Bunga Indonesia dan Produk Domestik Bruto Terhadap Volume Ekspor Impor di Indonesia. Journal Of Business \& Applied Management, 12(1), 1-11.

Langi, T. M., Maisnambow, V., \& Siwu, H. (2014). Analisis Pengaruh Suku Bunga BI, Jumlah Uang Beredar, dan Tingkat Kurs Terhadap Tingkat Inflasi di Indonesia. Jurnal Berkala Ilmiah Efisiensi, 14(2), 44-58. Retrieved from https:// ejournal. unsrat. ac. id/ index.php/ jbie/ article/ view/ 4184/3713

Maharani, D. P. P., Setiawina, N. D., \& Purbadharmaja, I. B. P. (2017). Pengauh Suku Bunga, Indeks Harga Konsumen dan Kurs Terhadap Jumlah Kredit Total dan Pertumbuhan Ekonomi Bali. E-Jurnal Ekonomi Dan Bisnis Universitas Udayana, 6(3), 1049-1078. Retrieved from https://ojs.unud.ac.id/index.php/EEB/article/view/24282

Mahendra, I. G. Y., \& Kesumajaya, I. W. W. (2015). Analisis Pengaruh Investasi, Inflasi, Kurs Dollar Amerika Serikat dan Suku Bunga Kredit Terhadap Ekspor Indonesia Tahun 1992-2012. E-Jurnal EP Unud, 4(5), $525-545$.

Putra, A. M. (2018). Pengaruh Inflasi, PDB, dan Suku Bunga Kredit Terhadap Penyaluran Kredit Bank di Indonesia (2007-2016). Jurnal Ilmiah Mahasiswa FEB, 7(1). Retrieved from http:// jimfeb.ub.ac.id/ index.php/ jimfeb/article/view/5216/4589

Sonia, A. P., \& Setiawina, N. D. (2016). Pengaruh Kurs, JUB dan Tingkat Inflasi Terhadap Ekspor, Impor dan Cadangan Devisa di Indonesia. Jurnal EP Unud, 5(10), 1077-1102. Retrieved from https:// ojs.unud.ac.id/ index.php/eep/article/view/23551/16072

Suhendro, D., \& Siregar, Z. A. (2019). Pengaruh Investasi dan Ekspor Terhadap Pertumbuhan Ekonomi Indonesia (Periode Tahun 2012 Sampai Dengan Tahun 2016). Tansiq: Jurnal Manajemen Dan Bisnis Islam, 2(1), 68-92. Retrieved from www.bkpm.go.id

Suryono, A. (2019). Pengaruh Nilai Tukar dan Jumlah Uang Beredar Terhadap Ekspor Indonesia Tahun 2009-2018. Forum Ekonomi, 21(2), 109-118. Retrieved from http://journal.feb.unmul.ac.id/ index.php/ Forumekonomi/ article/view/5912/582

Wardani, D. K. (2019). Pendeteksian dan Pemodelan Pencilan Pada Data Indeks Harga Konsumen (IHK) Kota Malang. Exact Paper in Compilation, 2(1), 75-82.

Wibowo, E. S., \& Syaichu, M. (2013). Pengaruh Suku Bunga, Inflasi, CAR, BOPO, NPF Terhadap Profitabilitas Bank Syariah. Diponegoro Journal 
The Influence Of Interest Rate, Money Circulation, Inflation, Sumantria

of Management, 2(2), 10-19. Retrieved from https:// ejournal3.undip.ac.id/ index.php/djom/article/view/2651

Yudhanto, A. K., Arifin, Z., \& Yulianto, E. (2019). Pengaruh Produksi Daging Sapi Dalam Negeri, Permintaan Daging Sapi, dan Harga Daging Sapi Internasional Terhadap Volume Impor Daging Sapi di Indonesia (Survei Pada Volume Impor Daging Sapi 2006-2013). Jurnal Administrasi Bisnis, 67(1), 1-7. Retrieved from http://administrasibisnis. studentjournal.ub.ac.id/index.php/jab/article/view/2782/3170 